\title{
Strategy Formulation And Csr Implementation On Company Performance(Study At Industrial Area Makassar)
}

\author{
Muhammad Yusuf, ${ }^{1}$ Eka Afnan Troena ${ }^{2}$, Made Sudarma ${ }^{3}$, Khusnul Ashar ${ }^{4}$ \\ Economics and Business Faculty of Brawijaya University, Malang, Indonesia
}

\begin{abstract}
This study was based on condition of CSR activities reality that identical to generic CSR programs. Company carrying out CSR implementation because of high external pressures, not an company internal awareness to contribute to improve social environment and have no connection with main activities and corporate strategy. Consequently, this does not benefit to company performance and competitive advantage. Focus of this research is to develop a study to examine leadership behavior in formulating corporate strategy that oriented to corporate social responsibility (CSR). Efforts to improve corporate performance be done through implementation of integrated CSR strategy at industrial area of Makassar (PT KIMA). The analysis unit is company. Respondents that become samples are 81 people with leadership and chief general manager level, company-level functional manager. Analysis methods to test hypothesis is Structural Equation Model (SEM) with variance-based program of Partial least Square (PLS).

The results of this study show that: antecedent variables, consisting of a transformational leadership style and ethical integrity significantly influence company strategy formulation with CSR orientation. Organizational learning culture did not significantly influence company strategy formulation with CSR orientation. Company strategy formulation with CSR orientation significantly influence implementation of CSR. Finally, CSR implementation significantly affect company performance.
\end{abstract}

Keywords: Transformational Leadership, Integrity ethics, Organizational Learning Culture, Strategy Formulation, CSR implementation and Corporate Performance.

\section{Introduction}

At the end of 20th century, CSR discourse began to get attention from participants of High-Level Conference (Earth Summit) in Rio Janeiro, Brazillia at 1992. They agreed to change the development paradigm of economic growth become sustainable growth. Derivation of this agreement impact on business sector. Companies face increasing pressure to does not only use a single bottom line, corporate value is reflected only by profitability level . Corporate responsibility, known as CSR pyramid developed by Carroll, Archi B. [1], should be understood holistically and based on triple bottom lines, ie profit, people and planet (3P)

Triple bottom line concept was proposed by Elkington [2] that company should develop responsibility orientation on three aspects, namely:

a. The Economics (Profit), company still must orient to seek economic advantage that allows it to continue to operate and grow.

b. environmental sustainability aspects (Planet), company cares for environment and sustainable biodiversity. Some programs based on CSR principles are a green environment, provision of clean water, improved housing, and tourism development (ecotourism).

c. Social environment aspect (People), a company must have a concern for human welfare. Some companies develop CSR programs such as scholarships for students around company, the establishment of educational and health facilities, strengthening the local economy capacity, and even there is a company that arranges social protection schemes for local residents.

The concept of CSR pyramid developed Archi B. Carroll [1] gives theoretical and logical justification why a company needs to implement CSR for the surrounding community (Saidi and Abidin) [3]. In Carroll's view, CSR is top pyramid that closely related, and even identical, to the philanthropic responsibilities. Furthermore, Carrol in Cristin [1] theorized CSR pyramid that social responsibility can be based on four dimensions: 1) Economic responsibility, it is the responsibility to generate profits for company. 2) Legal responsibility, responsibility for fulfilling the economy mission within applicable law framework, 3) Ethical responsibility, companies are doing something right and fair as a proper form of responsibility given to stakeholders, and 4) Discretionary Responsibility, it is corporate responsibility to contribute to social life, obligation is assumed to be purely voluntary in establishing good relations with community.

This pressure responded by company by implementing programs of generic corporate social responsibility (CSR) as a consequence and social and environmental responsibility. CSR generic programs do not have a connection to main activities and corporate strategy. Therefore, it does not contribute benefits to both company's performance and competitive advantage. During this time, CSR implementation is not optimal 
because company fulfill its social responsibility obligations only to fulfill stakeholders and regulator pressure, not corporate consciousness, Porter and Kramer [4]

Therefore, we define CSR committed to a particular group of stakeholders as policies, processes and practices adopted by company to stakeholders group. This study focused on major stakeholders and defines CSR through main stakeholders perspective. The survival and success of a company will depend on manager ability to create wealth and adequate satisfaction of major stakeholders, Clarkson [5]. Main stakeholders of a company are employees, shareholders, customers, suppliers, communities and the natural environment.

CSR implementation should use new approaches, such as the concept of corporate correspondence citizenshiporiented between social benefits that company provides for public from profit derived by a company (business profit) through implementation of corporate citizenship program, Jeurissen [6]

Lawrence and Weber [7] also states that if a corporation makes CSR as part of vision and strategy, the corporation's business will enjoy the reputation and increase business value and long-term earnings growth. The opinion was supported by the Corporate Sustainability Theory, Elkington [2], which states that in order to live sustainable, the corporation must integrate business goals with social goals and ecological objectives holistically.

An empirical study conducted Waldman et al. , [8] using the strategic leadership theory. It was examined the influence of transformational leadership on CSR aspects in the decision making process. Furthermore, Verissimo and Lacerda [9] develop a test the effect of transformational leadership and ethical integrity of Company's strategic orientation to CSR. Both studies found a positive relationship between transformational leadership on Company's strategic orientation to CSR. However Verissimo and Lacerda [9] did not find significant correlation between CEO ethics integration on company CSR orientation.

Some research link CSR, both in strategy and implementation level, with following consequences variables: organizational performance Lorenzo et al. , [10]; Skerlavaj et al. , [11] profitability, Mittal, et al. , [12] corporate sustainability, Kampf, [13] a competitive advantage, reputation and corporate image, Arendt and Brettel, [14]

Positioning CSR as part of company's strategy has been said by some management experts. Levine et al. [15] states that strategic CSR activities can increase competitive advantages range, such as brand reputation, awareness and employee morale and relationships with regulators and consumers. Graafland et al. , [16]; Verissimo and Lacerda [9] and Kranz and Santalo [17] found the companies implementing strategic CSR will improve performance and competitiveness.

CSR implementation in this study more oriented to the elaboration of internal and external aspects of company's. Mishra and flares [18] examined the effect of CSR implementation on corporate performance. The indicators developed to measure CSR implementation is stakeholder approach to employees and external perspective, which consists, investors perspective, public, an environmental and supplier perspective. The results of the studies have increased the aggregate CSR size to improve financial and non-financial performance. In addition, CSR is better / higher against each type of stakeholders to improve company performance.

Referring from various facts, theories and empirical outlined above, the research focus is to develop research at manufacturing in the industrial PT. Kima Makassar, to assess company's performance improvement through CSR implementation integrated with corporate strategy. CSR-oriented corporate strategy constructs measured by indicator of sustainability progress indicator comparative evaluation (SPICE), developed by Hemming et al. , [19]. The methodology is based on triple bottom line concept, Elkington [2], which combines measures of economic development with social and environmental responsibility.

II. Research Framework
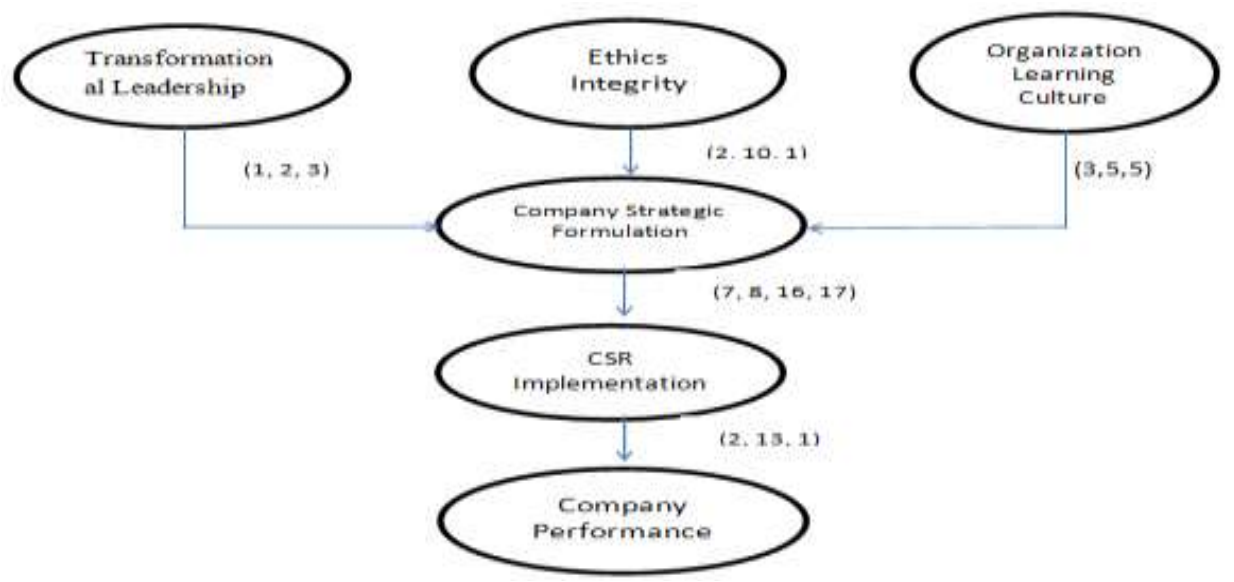
Description:

1. Athena Xenikou, (2006)

10. Udiyaningsih (2005),

2. Jose M Verissimo and Lacerda (2011),

3. Waldman et al. , (2004),

11Turner, et al. , (2002),

4. David A., Siegel, Donald S. . (2006),

12. Parry, K. W. . (2002)

13. Mishra, and Suar, (2010).

5. Fang dan Wang (2006),

6. Miha Skerlavaj, et al. , (2007)

7. Elkington, J. (1997).

8. Freeman, R. E. (2004)

9. Graham, J. W. (1995).

14. Daniel Fernandez-Kranz, , (2010

15. Loreandnzo, et al. , (2008),

16. Berman, et al. , (1999), ”

17. Hemming et al. , 2004

\section{A. Leadership, Ethics Integrity, Organizational Learning Culture}

Several theories and previous research become bases of this research to build variables and formulating model the relationship between the variables under investigation. Aspects of behavior and leadership style in formulating corporate strategy CSR- oriented are follows.

\section{Leadership}

Thoha [20] states that research Iowa, Ohio and Michigan became a milestone in history the commencement of leadership study related to organizational behavior. Leadership theory, among others are: 1) Trait Theory, which is known as the theory Great Man, 2) Group theory, related to social psychological, 3) Theory and Model of situational contingencies, affect the role of a leader in performing its function as a leader, so that subordinates confident and happy for his leadership, and 4) Path-Goal Theory, using motivation theory to direct subordinates in order to work properly.

Leadership style each leader different each other. Authoritarian leadership style provide opportunities for subordinates to ask questions or ask for clarification. Democratic leadership style give opportunity for subordinates to discuss; Laissez-Faire leadership style give freedom to subordinates (The Iowa Leadership Study), Luthans [21]

Bass and Avolio [22] in wawan-satu.blogspot.com suggested that transformational leadership is known as "the fours'. Firstly, idealized influence, a reflection of subordinates behavior in admiring boss. Secondly, inspirational motivation, able to motivate subordinates to maximum work in achieving organizational goals. Thirdly, intellectual stimulation, leaders must be able to create new ideas that will impact on organization development. Fourth, individualized consideration, the leader must be able to listen to and meet the needs of subordinates, in other words, leader cares to his subordinates.

Transformational leadership is superior compared to transactional leadership, Daft [23]. A transactional leader pay more attention to subordinates needs that can increase productivity, so that subordinates work happily without any coercion. However, transformational leaders capable to implement the changes in vision, mission, and organization culture as a whole by influencing his subordinates to make changes to increase productivity or performance of organization, Daft [23]

\section{Ethics Integrity}

Integrity is defined as ethics virtue that can raise the level of human aspirations and ethical behavior and have a transformative effect on leaders and followers, Burns [24]. Transformational leadership occurs when goal value of a leader such as integrity, respect and justice is adopted by subordinates (Kuhnert and Lewis [25]. Construct used to measure the CEO ethical integrity is the Perceived Leader Integrity Scale (PLIS) developed by Craig and Gustafson, [26]. This is a subordinate instrument that quantifies perception of behavior style a leader.

Business ethics and social responsibility needs to be cultivated in any "corporate" behavior simultaneously. In essence, a company that cares about ethics will create loyal customers. Therefore, company survival in long run is more assured. Insights and ideas that need to be businesses concern for ethics enforcement are: (1). self-control (2). social sensitivity (3). competition (4) large companies can help small companies (5) looking ahead (6) maintain identity.

\section{Organizational Learning Culture}

Organizational Learning Culture is defined as a complex process that refers to development of new knowledge and having potential to change behavior. Huber, Slater and Narver, in Skerlavaj et al. [11], Skerlavaj et al., [11] suggests that indicators of organizational learning culture are combination of three processes: (1) acquisition, (2) Distribution, (3) Interpretation of information and mindset change. This Indicators were used in this study. 
The benefits of learning cultural development are assessed by performance or effectiveness of organization. Thus, a comprehensive learning culture needs to be placed within organization transformation framework in maintaining its existence, such as the creation of superior value for different stakeholder groups.

\section{B. Company strategy formulation Oriented to Corporate Social Responsibility (CSR)}

CSR-oriented company strategy formulation incorporates a holistic perspective of a future-oriented company, either external forces or internal forces, in order to achieve its goals and realize its strategic plan based on the ecological balance, Freeman, [27]. Company's strategy is based on triple button line concept of Elkington [2] namely: profit, people and planet. The indicators used to measure the CSR-oriented corporate strategy variables was developed by Hemming et al. , [19], which consists of: 1) Compliance Management, 2) Environmental Management System, 3) Improved Performance, 4) environmental and sustainability reports, 5) Stakeholder Dialogue, 6) Control Products, 7) Supply Chain Management, 8) Eco-Innovation, 9) Contribution to Quality of Life and Community Involvement, and 10) Employer Of Choice

Implementation of Corporate Social Responsibility (CSR) is a concept in which companies pay attention to social and environmental integration in business operations and in their interaction to stakeholders is voluntary, Commission Of The European Communities (2001). The indicators used to measure the CSR implementation variables has been developed by Mishra and flares [18], who prefers to wealth creation and adequate satisfaction for our stakeholders, primarily consisting of 1) employee, 2) consumer, 3) investor, 4) society, 5) environmental, and 6) suppliers perspectives.

Strategic performance measurement is used to measure the performance appraisal of all aspects and functions within company, and its implications not only affects the short term but the medium and long term, as well as performance-oriented aspects of financial and non-financial performance, (Kaplan and Norton, 1996). Indicators to measure the performance variable is balance scorecard, with four perspectives namely: 1) Financial, 2) the consumer, 3) internal business process, and 4) learning and growth perspective.

\section{Research Methodology}

The research was conducted at PT. KIMA (Makassar Industrial Area), South Sulawesi Province. The approach used is quantitative. The population was 165 manufacturing companies operating in Industrial Area Makassar, South Sulawesi. Sample used was taken by using purposive sampling, namely 81 companies manufacture. In this case, the respondent represented by leader with general manager level and functional managers. Questionnaires contain a set of indicators that reflect latent variables and items in closed statement prepared with a Likert scale measurement. Validity and reliability test are also performed. Research model is tested using statistical analysis techniques PLS (Partial Least Square), Solimun [28]

\section{A. Hypothesis Testing Results of Structural Model (Inner Model) \\ V. Testing Hypotheses}

Hypothesis in this study is tested using inner model (structural model). It consists of 5 (five) hypothesis on 3 (three) endogenous variables. Three first hypothesis states that Transformational leadership (X1), Integrity Ethics (X2) and organizational learning culture (X3) have a significant influence on CSRoriented company strategy formulation (Y1). Another hypothesis consists are the influence of strategy formulation (Y1) on CSR implementation (Y2) and CSR Implementation (Y2) on BSC performance (Y3). The results of hypothesis testing can be seen in the following figure:

Figure 5.1

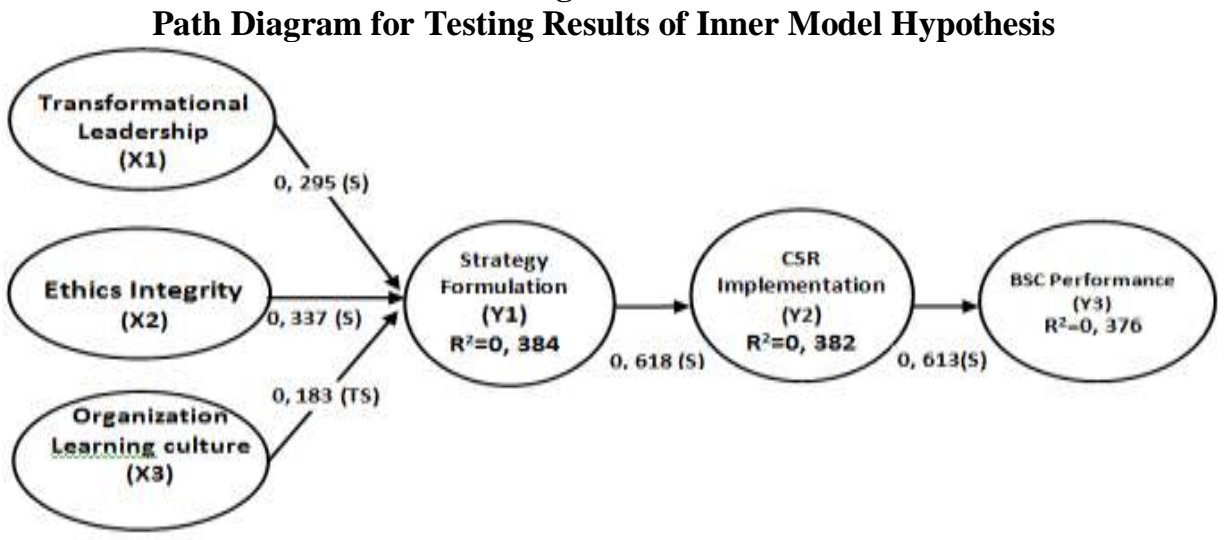

Source: Data processed (2012)

Description S = (Significant Line), TS = (Path Not Significant $)$ 
Table 5. 1

Path Coefficients Testing Results In Inner Model

\begin{tabular}{|l||c|c|c||c|c|}
\hline \multicolumn{1}{|c||}{ Variable } & $\begin{array}{c}\text { Original } \\
\text { Sample } \\
(\mathbf{O})\end{array}$ & $\begin{array}{c}\text { Sample } \\
\text { Mean (M) }\end{array}$ & $\begin{array}{l}\text { Standard } \\
\text { Deviation } \\
\text { (STDEV) }\end{array}$ & $\begin{array}{l}\text { Standard } \\
\text { Error } \\
\text { (STERR) }\end{array}$ & $\begin{array}{l}\text { T Statistics } \\
\text { (O/STERR }\end{array}$ \\
\hline $\begin{array}{l}\text { Learning culture } \rightarrow \text { Strategy } \\
\text { Formulation }\end{array}$ & 0.162853 & 0.185925 & 0.116386 & 0.116386 & 1.399248 \\
\hline $\begin{array}{l}\text { Strategy Formulation } \rightarrow \text { CSR } \\
\text { Implementation }\end{array}$ & 0.618085 & 0.626324 & 0.066991 & 0.066991 & 9.226337 \\
\hline $\begin{array}{l}\text { CSR Implementation } \rightarrow \text { BSC } \\
\text { Performance }\end{array}$ & 0.612851 & 0.621685 & 0.062685 & 0.062685 & 9.776644 \\
\hline $\begin{array}{l}\text { Ethics Integrity } \rightarrow \text { Strategy } \\
\text { Formulation }\end{array}$ & 0.336880 & 0.343671 & 0.080798 & 0.080798 & 4.169413 \\
\hline $\begin{array}{l}\text { Transformational Leader } \rightarrow \\
\text { Strategy Formulation }\end{array}$ & 0.295075 & 0.279786 & 0.093300 & 0.093300 & 3.162655 \\
\hline
\end{tabular}

Source: Data processed (2012)

Hypothesis Testing 1 is accepted. The test results show there is a significant effect of transformational leadership variable on CSR-oriented company strategy formulation. Therefore, the first hypothesis in this study is acceptable because it has a significant effect.

Hypothesis Testing 2 is accepted. The test results show there is a significant effect of ethical integrity variable on CSR-oriented company strategy formulation. Therefore, the second hypothesis in this study is acceptable because it has a significant effect.

Hypothesis Testing 3 is rejected. The test results show the relationship between organizational learning culture variable with CSR-oriented company strategy formulation is not accurate. Therefore, the third hypothesis in this study is not acceptable because it has not a significant effect.

Hypothesis Testing 4 is accepted. The tests result show there is significant impact of CSR-oriented company strategy formulation variable on CSR implementation. Therefore, the fourth hypothesis in this study is acceptable because it has a significant effect.

Hypothesis Testing 5 is accepted. It show there is significant effect of CSR implementation variable on corporate performance as measured by BSC. Therefore, the fifth hypothesis in this study is acceptable because it has a significant effect.

\section{B. Total Coefficient of Determination (Q2)}

The goodness of fit for inner model shows total R-square coefficient of 0.762 . The results can be explained in that the research model that examined the effect of Transformational Leadership (X1), Integrity ethics (X2) and learning culture (X3) on strategy formulation (Y1) and their effects on CSR Implementation (Y2) and Balanced Scorecard Performance (Y3) has a high relevant predictions. Predictive value relevance of 0.762 indicates that the data diversity (information load) in this study may be explained by the research model by $76.2 \%$, while the remaining $23.8 \%$ is explained by other variables that not surveyed in this research model .

\section{Research Finding}

The results of hypothesis testing in Table 5.1, with concerning the direct effect between variables and the significance, create a model about the influence of transformational leadership, ethics integrity on CSRoriented company strategy formulation, CSR implementation and performance of manufacture company in Makassar Industrial Area. The explanation are follows:

Factor loading values of transformational leadership style suggests that this idealized influence indicator reflect the subordinate admire to their admired boss. This leadership style most used by leader, specially at companies within the industrial area of Makassar. But generally, the results showed that all four indicators strongly reflect the transformational leadership style. The findings of this study strengthen study by Bass and Avolio [23] that transformational leadership is known as "the fours'. Firstly, idealized influence: a reflection of boss that admired by subordinates. Secondly, inspirational motivation, able to motivate subordinates to work with maximum effort to achieve organizational goals. Thirdly, intellectual stimulation, the leader must be able to create new ideas that will impact on organization development. Fourth, individualized 
consideration: the leader must be able to listen and to meet subordinates needs, in other words, a leader very care to his subordinates.

Empirically, the findings of this study support the opinions expressed Jose M Verissimo and Lacerda [9] in a study that examined the influence of transformational leadership and ethical integrity on CSR-oriented corporate strategy.

Integrity ethics affect CSR-oriented company strategy formulation. It shows there is a positive influence between leader integrity on strategy formulation. The results of descriptive analysis shows that respondent general is agreed to ethics integrity of directors board that reflecting high morality to employees.

The relationship between organizational learning culture variables with CSR-oriented strategy formulation is not accurate (insignificant), because it has no significant effect. Empirical reality suggests there are other factors that are more dominant in organizational learning process, intuitive cognition.

CSR-oriented company strategy formulation affect on CSR implementation. These findings are consistent with corporate sustainability theory proposed by Elkinton [2] Kranz and Santalo [17] concerning the field thinking and practice. Companies and other business organizations working to extend the life expectancy based on triple bottom line aspects namely: profit, planet and place, in competition and company survival context . Profit indicator with a score of 0.70 is an indicator with highest average value of CSR-oriented company strategy formulation. This study concluded that CSR, with dimensions of value creation in three aspects: economic (Profit), environmental sustainability (Planet), and social (People), can be an integral part of company's strategy, particularly manufacturing companies operating in Makassar Industrial Area.

CSR implementation focused on key stakeholders and define CSR through main stakeholders perspective, comprising: employee, consumer, investor, community, environmental and supplier perspective. The test results accept hypothesis that CSR implementation affect on performance of Balanced Scorecard (BSC), this result supports the idea Mishra and flares [18], Berman et al., [29] which examined the effect of CSR implementation on corporate performance, and tested the six dimensions of corporate social responsibility (CSR) on financial performance (FP) and non-financial performance (NFP) of manufacturing company. The findings suggest that responsible business practices against major stakeholders contribute benefit to improved performance, especially companies operating in Makassar Industrial Area.

\section{Conclusion}

This study proves that behavioral aspects of leadership, consisting of transformational leadership, ethical integrity, increase the effectiveness of company strategy formulation oriented to ecological environment in the industrial area of Makassar. Dimensions of idealized influence, inspiration motivation, intellectual stimulation and individualized consideration have significant and positive contribution to direction of company strategy formulation that increasingly CSR-oriented. Organizational learning culture does not make a real contribution to formulation of corporate strategy with environment oriented (CSR). The dimensions of acquisition and interpretation of information and behavioral dimensions of company leadership received a low response from company leaders because the intuition dimensions is more dominant aspect of organizational learning culture which is believed to increase the effectiveness of company strategy formulation.

The dimensions of the natural environment (planet), social environment (people) and economic dimension (profit) in CSR-oriented company strategy formulation have very significant contribution to improve the effectiveness of CSR implementation. Company strategy formulation orients to environment (planet, people, profit) will increase the leadership commitment to create CSR implementation in main stakeholders perspective, namely; employees, customers, investors, communities, environment and supplier perspective. This study shows that CSR implementation contributed significantly to improved company performance, measured by balanced scorecard (BSC) perspective. The wider perspective of CSR implementation adopted by industrial companies, the higher performance, the better financial performance (profit) as well as an increase in nonfinancial performance (customer perspective, business process, and learning and growth).

This study findings show the importance to integrate CSR implementation with company strategy formulation to contribute benefits optimally, both to improve performance and company sustainability. The research results provide implications for regulators related to CSR implementation in business organizations, in order to give more space and independence for company in determining the approach, methods and forms of CSR implementation programs integrated with each corporate strategy.

\section{References}

[1] Carroll, Archie B.1979. A Three Dimentional Conceptual Model of Corporate Performance, The Academy of Management Review, Vol.4, October.

[2] Elkington, J. (1997). Cannibals with Forks: Triple Bottom Line of 21st Century Business. Capstone Publishing, Oxford.

[3] Saidi, Zaim dan Hamid Abidin, (2004), Menjadi Bangsa Pemurah: Wacana dan Praktek Kedermawanan Sosial di Indonesia, Jakarta : Piramida

[4] Porter dan Kramer (2006), The link between competitive Advantage and Corporate social Responsibility, Harvard Business school publishing corporation, all rights reserved 
[5] Clarkson, M. B. E.: 1995, A Shareholder Framework for Analyzing and Evaluating Corporate Social Performance', Academy of Management Review 20(1), 571-610.

[6] Jeurissen, Ronald, (2004), Institutional Conditions of Corporate Citizenship., Journal of Business Ethics ., Volume 53., Numbers 12., pg.87-96

[7] Lawrence \& Weber,. (2002). Business and society : corporate strategy, Public policy, Ethics (tenth edition). New York : McGrawHill.

[8] Waldman, David A., Siegel, Donald S. and Javidan, M. (2006). Components of CEO Transformational Leadership and Corporate Social Responsibility. Journal of Management Studies, Dec. 2006,43,8,1703-1725.

[9] Verissimo and Laeerda, (2011),The new age of corporatesocial and ethical consciousness: Toward a new leadership mindset, Proceedings of the $12^{\text {th }}$ Annual International Leadership Association (www.ila-net.org) Conferens. Leadership 2.0: Time for Action, 27 Oct - 30 Oct., Boston, USA.

[10] Lorenzo, et. al.(2008)., Social responsibility in Spain Practices and motivations in firms, Management Decision Vol. 46 No. 8, 2008pp. 1247-1271.

[11] Skerlavaj et.al.(2007), Organizational Learning Culture-the missing link between business process and organizational performance, Internatioal Journal of Production Economics, 106 p. 346-367.

[12] Mittal, R.K., N.S. and Archana Singh, 2008. 'An Analysis of Linkage Between Economic Value Added and Corporate Social Responsibility', http//www.emeraldinsight.com/0025-1774.htm. Accesed 12 April 2005.

[13] Kampf, C, 2007, “Corporate Social Responsibility”, Corporate Communications: an International Journal, vol 12 No.1, pp. 41-57.

[14] Arendt dan Brettel, 2010, Understanding the influance of corporate social responsibility on corporate identity, image, and firm performance, Management Decision vol. 48. No. 10, 2010 pp.1469-1492.

[15] Levine, M.A.,2008. “China's CSR Expectations Mature, With PRC Stock Journal of Producton Management. Vol.10 No.3 pp, $32-45$

[16] Graalfand, J., Van De Ven, B. and Stoffele, N. (2003), "Strategies and instruments for organizing CSR by small and large businesses in The Netherlands", Journal of Bussiness Ethics, Vol.47, pp. 45-60.

[17] Kranz Dan Santalo, 2010, When Necessity Becomes A Virtue: The Effect Of Roduct Market Competition On Corporate Social Responsibility, Journal Of Economics \& Management Strategy, Volume 19, Number 2, Summer 2010,453-487

[18] Mishra, and Suar, 2010. 'Does Corporate Social Responsibility Influence Firm Performance of Indian Companies?', Jouirnal of Business Ethics 95:571601.

[19] Hemming, et al.,. (2004). Strategies for sustainable development: use of a benchmarking tool to understand relative strengths and weaknesses and identify best practice. Corporate Social-Responsibility and Environmental Management, 11, 2, $103-113$.

[20] Thoha, Miftah. 2010. Kepemimpinan dalam Manajemen, PT. Raja Grafindo Persada, Jakarta.

[21] Luthans and Hodgetts, 2009. International Management : Culture, Strategy, And Behavior, Seventh Edition. Mc Graw.Hill, International Edition.

[22] Bass, B.M, and Avolio, B.J,1994, Spring, Transformational Leadership and Arganizationall Culture, Public Administration Quartely.

[23] Daft, L, Richard. 2O10. Era Baru Manajemen, Buku 2, Edisi 9, Salemba Empat, Jakarta.

[24] Burns, J.M. (1978), Leadership, Harper \& Row, New York, NY.

[25] Kuhnert K. W. and P. Lewis: 1987, 'Transactional and Transformational Leadership: A Constructive/Developmental Analysis', Academy of Management Review 12(4), 648-657.

[26] Craig, S. B. and Gustafson, S. B. (1998). 'Perceived leader integrity scale: an instrument for assessing employee perceptions of leader integrity'. The Leadership Quarterly, 9,127-45.

[27] Freeman, R.E. 1984. Strategic Management A Stakeholder Approach. Boston: Pitman.

[28] Solimun,2010. Analisis Multivariat Pemodelan Struktural, Metode Partial Least Square, Cetakan Pertama., CV. Citra Malang.

[29] Kaplan. R.S and D.P. Norton. 1992. The Balanced Scorecard - Measure That Drive Performance, Harvard Business Review, January - pebruary: pp 71-79. 